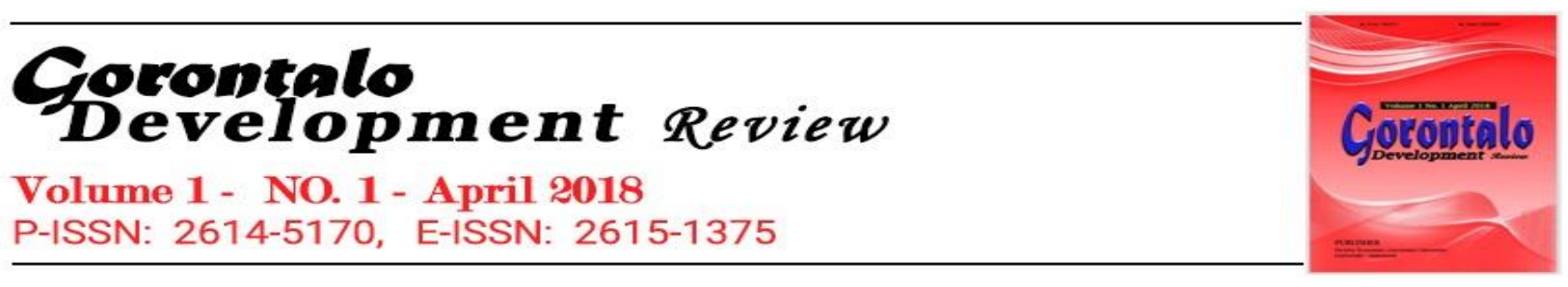

\title{
Pengaruh Kepemimpinan, Tanggung Jawab, Kedisiplinan Dan Kerjasama Terhadap Kinerja Pegawai di Universitas Gorontalo
}

\author{
Nurdin Yusuf \\ Studi Pembangunan, Fakultas Ekonomi Universitas Gorontalo \\ email: nurdinyusuf37@yahoo.co.id
}

\begin{abstract}
The study aims to determine and analyze the influence factors of leadership, responsibility, discipline and cooperation affect the performance of employees at Gorontalo University. And To know and analyze the dominant factor that affects the performance of employees at Gorontalo University in Gorontalo.

This research was carried out research was conducted at the University of Gorontalo, with consideration of location is one of the central services in the field of education so that employees are required to provide excellent service in a professional manner. Purposive sampling was conducted as many as 105 employees. Data were analyzed using multiple regression analysis.

The results showed that Simultaneously shows that the leadership (X1), responsibility (X2), discipline (X3) and cooperation (X4) effect on employee performance $(Y)$. The value $R$ square $=0.827$. While the correlation coefficient $R=0.909$ Partially indicates that the variable has a positive leadership and dominant to employee performance, Partially indicates that the variable has a positive leadership and dominant to employee performance indicates that the variable Partially responsibility has a positive and significant impact on employee performance partially indicates that the variable has a positive discipline and significant impact on employee performance Partially indicates that the variable has a positive cooperation and significant impact on employee performance, Gorontalo University in Gorontalo.

Keywords : leadership, responsibility, discipline, cooperation and performance of employees
\end{abstract}

\section{PENDAHULUAN}

Universitas Gorontalo sebagai penyelenggara lembaga pendidikan tinggi di Kawasan Timur Indonesia harus mencermati kecenderungan perkembangan global ke arah terciptanya apa yang disebut dengan dunia koneksitas. Oleh karena itu, Universitas Gorontalo harus memiliki komitmen mutlak untuk meningkatkan produktivitas sumber daya pegawai yang mampu menguasai teknologi serta memiliki kemampuan yang prima untuk melaksanakan visi dan strategis organisasi perguruan tinggi. 
Faktor penilaian obyektif memfokuskan pada fakta yang bersifat nyata dan hasilnya dapat diukur, misalnya kuantitas, kualitas, kehadiran dan sebagainya. Sedangkan faktor-faktor subyektif cenderung berupa opini seperti sikap, kepribadian, penyesuaian diri dan sebagainya. Faktor-faktor subyektif seperti pendapat dinilai dengan meyakinkan bila didukung oleh kejadiankejadian yang terdokumentasi. Dengan pertimbangan faktor-faktor tersebut diatas maka dalam penilaian kinerja harus benar-benar obyektif yaitu dengan mengukur kinerja pegawai yang sesungguhnya atau mengevaluasi perilaku yang mencerminkan keberhasilan pelaksanaan pekerjaan. Penilaian kinerja yang obyektif akan memberikan feed back yang tepat terhadap perubahan perilaku ke arah peningkatan produktivitas kinerja yang diharapkan.

Penilaian kinerja dengan berbagai bentuk seperti key performance indicator atau key performance Index pada dasarnya merupakan suatu sasaran dan proses sistimatis untuk mengumpulkan, menganalisa dan menggunakan informasi untuk menentukan efisiensi dan efektivitas tugastugas karyawan serta pencapaian sasaran. Menurut Armstrong (1998), penilaian kinerja didasarkan pada pengertian knowledge, skill, expertise dan behavior yang diperlukan untuk mengerjakan pekerjaan dengan baik dan analisa lebih luas terhadap attributes dan perilaku individu. Dalam manajemen kinerja kompetensi lebih berperan pada dimensi perilaku individu dalam menyesuaikan suatu pekerjaan dengan baik. Attributes terdiri dari knowledge, skill dan expertise.

Dari data awal diperoleh keterangan yang mengindikasikan masih banyak pegawai di lingkup Universitas Gorontalo yang kurang memiliki kompetensi profesional, nampak bahwa tingkat pendidikan pegawai masih banyak yang berpendidikan SMA, tingkat keterampilan juga tergolong masih rendah, hal ini didasarkan pada beberapa pegawai yang belum menguasai komputer, kurang terampil dalam mengerjakan tugas yang diberikan atasan. Sikap dan perilaku pegawai belum sepenuhnya mencerminkan sikap atau perilaku yang diharapkan oleh pimpinan. Sedangkan tanggung jawab pegawai belum tinggi, hal ini terlihat dari banyaknya pekerjaan yang tertunda, yang tidak selesai tepat pada waktunya. Hal ini merupakan salah satu sikap yang tidak bertanggung jawab dari pegawai yang bersangkutan.

Data hasil penelusuran peneliti menunjukkan bahwa kepemimpinan belum berjalan efektif, hal ini terlihat dari banyaknya pegawai yang belum mengetahui kebijakan-kebijakan yang dibuat untuk mahasiswa ataupun pegawai. Begitu juga tanggung jawab pegawai terhadap pekerjaan dianggap masih rendah yang dapat dilihat dari masih banyaknya pekerjaan yang terbengkalai yang tidak selesai tepat waktu. Kedisiplinan pegawai juga dianggap masih rendah yang dapat dilihat dari masih banyak pegawai yang datang terlambat dan pulang sebelum jadwal pulang. Sedangkan kerjasama antara pegawai dianggap masih rendah, pegawai cenderung jalan sendirisendiri dan kurang memperhatikan pekerjaan teman sejawat.

Berdasarkan uraian dalam latar belakang, maka masalah pokok dalam penelitian dapat dirumuskan sebagai berikut:

1. Apakah faktor kepemimpinan, tanggung jawab, kedisiplinan dan kerjasama berpengaruh terhadap kinerja pegawai pada Universitas Gorontalo? 
2. Faktor apakah yang dominan berpengaruh terhadap kinerja pegawai pada Universitas Gorontalo?

\section{TINJAUAN PUSTAKA}

\subsection{Pengertian Manajemen Sumber Daya Manusia}

Menurut Hasibuan (2002:10), manajemen sumber daya manusia adalah : "Ilmu dan seni mengatur hubungan dan peranan tenaga kerja agar efektif dan efisien membantu terwujudnya tujuan perusahaan, karyawan dan masyarakat".

\subsection{Kinerja Pegawai}

Kinerja atau performance menurut Prawirosentono (1997 : 2) adalah hasil kerja yang dapat dicapai oleh seseorang atau sekelompok orang dalam suatu organisasi sesuai dengan wewenang dan tanggung jawab masingmasing dalam rangka mencapai tujuan organisasi bersangkutan secara legal, tidak melanggar hukum dan sesuai dengan moral maupun etika".

"Prestasi kerja ditentukan oleh kapasitas kerja dan kesediaan bekerja. Sedang kesediaan bekerja ditentukan oleh (1) obyek pekerjaan sifat dan fungsi yang akan dilaksanakan, (2) Moril kolektivitas kerja, dan (3) fungsi upah). Selain pendapat beberapa ilmuwan di atas, Mangkunegara (2001 : 67) berpendapat bahwa prestasi kerja adalah hasil kerja secara kualitas dan kuantitas yang dicapai oleh seorang pegawai dalam melaksanakan tugasnya sesuai tanggung jawab yang diberikan.

Dari batasan tersebut di atas dapat disimpulkan bahwa kinerja merupakan hasil kerja seseorang selama suatu periode tertentu dibandingkan dengan standar kerja, target atau sasaran atas kriteria yang telah ditentukan terlebih dahulu dan telah disepakati bersama baik secara kualitas maupun kuantitas.

\subsection{Faktor-Faktor Yang Berpengaruh Terhadap Kinerja Pegawai}

Dalam melakukan penilaian terhadap pelaksanaan pekerja atau penilaian karya atau juga disebut penilaian prestasi kerja seseorang karyawan harus memiliki pedoman dan dasar penilaian. Pedoman dan dasar penilaian tersebut dapat dibedakan dalam aspek-aspek penilaian. Yang dimaksud dengan aspek penilaian disini hal-hal yang pada dasarnya merupakan sifatsifat atau ciri-ciri yang dapat menunjukkan bahwa pelaksanaan suatu pekerjaan tertentu dapat berjalan dengan lancar dan berhasil dengan baik atau dengan kata lain ciri-ciri dari pelaksanaan pekerja yang digunakan kembali untuk menilai setiap pelaksana pekerja yang bersangkutan secara rutin.

Sebagai mitra pengusaha dalam melaksanakan tugas serta tanggung jawab setiap karyawan dipercaya menyelenggarakan kegiatan produksi/perusahaan sesuai dengan bidangnya masing-masing dalam rangka pencapaian tujuan perusahaan serta umum. Oleh karena itu aspek-aspek penilaian yang dapat diterapkan dalam hal ini misalnya, rasa tanggung jawab, kesetiaan dan pengabdian, prakarsa, kejujuran, disiplin, kerjasama, kepemimpinan.

Soeprihanto (1996 : 24-25) menyebutkan bahwa yang perlu dipertimbangkan oleh bagian personalia umumnya berbeda, sesuai dengan level karyawan yang dinilai. Misalnya tingkatan karyawan dapat dikelompokan menjadi 4 kelompok, yaitu level operator, level foremen, level 
.supervisor, dan level kepala bagian keatas. Tingkatan dan faktor-faktor yang umumnya perlu dinilai adalah sebagai berikut:

1. Level Operator ; (a) Prestasi kerja, (b) Tanggung jawab, (c) Ketaatan, (d) Kejujuran, dan (e) Kerjasama

2. Level foreman; (a) Prestasi kerja, (b) Tanggung jawab, (c) Ketaan (d) Kejujuran, (e) Kerjasama, dan (f) Kepemimpinan.

3. Supervisor ; (a) prestasi kerja, (b) Tanggung jawab, (c) Ketaatan (d) Kejujuran, (e) Kerjasama. (f) Parakarsa. dan (f) Kepemimpinan

4. Level Kepala Bagian Keatas; (a) Prestasi Kerja, (b) Tanggung Jawab, (c) Ketaatan, (d) Kejujuran. (e) Kerjasama. (f) Prakarsa, (g) Kepernimpinan

Flippo (1995 : 249) mengemukakan bahwa pemilihan faktor-faktor yang harus diukur di dalam penilaian prestasi kerja merupakan bagian yang menentukan dalam sistem skala grafik. Faktor-faktor tersebut mempunyai dua jenis: (1) sifat-sifat khusus, seperti inisiatif dan ketangguhan, dan (2) sumbangan, seperti jumlah dan mutu kerja. Karena bidang-bidang tertentu dari prestasi kerja tidak dapat diukur secara objektif, adalah mungkin skala grafis itu akan menggunakan campuran dari sifat-sifat khusus dan sumbangan, dengan memberikan tekanan pada yang terakhir. Selanjutnya disebut pula bahwa jumlah faktor yang biasanya dipakai didalam penilaian prestasi kerja bervariasi dari sembilan sampai dua belas dan disesuaikan dengan kategori jabatan tertentu yang sedang dipertimbangkan, biasanya faktor-faktor yang dipakai adalah kuantitas kerja, kerjasama, kepribadian, kepandaian yang beraneka ragam, kepemimpinan, keselamatan, pengetahuan, pekerjaan, kehadiran, kesetiaan, ketangguhan, dan inisiatif.

Yoder dalam Manullang (1987 : 122) menyebutkan hasil penelitian di Amerika serikat, dilaporkan bahwa terdapat beberapa sifat yang paling umum dinilai dari pegawai bekerja dengan tangan atau pegawai di bidang produksi dan pegawai yang bekerja di bidang tata usaha dan dari pegawai yang berposisi sebagai pemimpin sebagai berikut :

a. Sepuluh sifat yang paling umum dinilai dari pegawai dibidang produksi adalah; (1) quality; (2) quatity of work; (3) knowledge of job; (4) dependability; (5) cooperration; (6) adaptability; (7) attendance; (8) versatility; (9) house keeping clan dan (10) safety.

b. Sepuluh sifat yang paling umurn dinilai pegawai tata usaha adalah sebagai berikut: (1) quality; (2) dependability; (3) quality of work; (4) knowledge of job, (5) coopertion; (6) initiative; (7) adapbility; (8) jubgement; (9) attendence dan (10) health.

c. Sepuluh sifat yang paling umum dinilai dari orang yang memegang posisi pemimpin adalah sebagai berikut: (1) knowledge of job; (2) coopration; (3) dependibilyti; (4) qualiti of work; (5) judgement; (6) initiative; (7) quantity of work; (8) leadership; (9) planning and organization dan (10) health.

Pasal 4 PP NO. 10 tahun 1979 (Saydam, 1996 : 54) disebutkan bahwa unsur-unsur dalarn Daftar Penilaian Pelaksanaan Pekerja (DP3) yang dinilai ada 8 macam, yaitu; kesetiaan, prestasi kerja, tanggung jawab, ketaatan, kerjasama, kejujuran, prakarsa, dan kepernimpinan.

Berdasarkan hal tersebut di atas, maka dalam penelitian akan dikaji empat variabel yaitu : kepemimpinan, tanggung jawab, kedisiplinan dan kerjasama. 


\subsection{Lokasi dan Waktu Penelitian}

\section{METODE PENELITIAN}

Penelitian ini dilaksanakan pada Universitas Gorontalo, Penelitian dilaksanakan selama tiga bulan yaitu dimulai bulan Juni sampai dengan akhir bulan Agustus 2013

\subsection{Metode Pengumpulan Data} meliputi :

Metode pengumpulan data yang digunakan dalam penelitian ini

1. Observasi, yaitu melakukan pengamatan langsung pada aktivitas kerja pegawai yang berkaitan dengan kinerja pegawai, kepemimpinan, tanggung jawab, kedisiplinan dan kerjasama pada Universitas Gorontalo di Gorontalo.

2. Kuesioner, yaitu mengumpulkan data dengan jalan mengedarkan angket kepada responden yang ditetapkan sebagai sampel penelitian yang berisi pertanyaan-pertanyaan mengenai masalah yang diteliti .

3. Dokumentasi yaitu pengumpulan data melalui dokumen instansi yang diteliti (Universitas Gorontalo).

\subsection{Jenis dan Sumber Data}

\section{Jenis Data}

a. Kualitatif yaitu analisis berupa kalimat-kalimat atau paragrap yang menggambarkan, menjelaskan serta menguraikan berbagai hal yang berkaitan dengan kegiatan di Universitas Gorontalo.

b. Kuantitatif yaitu analisis dengan menampilkan perhitungan angkaangka dalam bentuk tabel-tabel.

\section{Sumber Data}

a. Data Primer adalah data yang diperoleh dari hasil penelitian langsung di lapangan yang diperoleh melalui wawancara, penyebaran angket (daftar pertanyaan) yang diajukan kepada responden.

b. Data Sekunder yakni data yang diperoleh dari tempat penelitian meliputi data yang dipublikasikan atau yang tidak dipublikasikan. Tentunya data ini berkaitan dengan lembaga dan yang berhubunagn dengan strategi pengembangan sumber daya aparatur.

\subsection{Populasi dan Sampel}

Populasi pada umumnya berarti keseluruhan obyek penelitian, mencakup semua elemen yang terdapat dalam wilayah penelitian. Mardalis dalam Arikunto (1999 : 53) mengemukakan bahwa "populasi meliputi semua individu yang menjadi sumber pengambilan sampel".

1. Populasi adalah keseluruhan elemen yang dijelaskan oleh seorang peneliti di dalam penelitiannya. Populasi dalam penelitian ini adalah seluruh pegawai pada Universitas Gorontalo yang berjumlah 105 orang

2. Sampel penelitian adalah wakil dari populasi. Dengan mempertimbangkan sedikitnya jumlah pegawai yang ada, maka penulis menjadikan seluruh pegawai tersebut sebagai sampel penelitian. Dengan demikian, penelitian ini menggunakan prosedur penelitian sensus. Selengkapnya dapat dilihat pada Tabel 1 berikut: 
Tabel 1. Populasi Penelitian

\begin{tabular}{|c|l|c|}
\hline No & UNIT KERJA/FAKULTAS & POPULASI \\
\hline 1 & BIRO AKADEMIK & 4 \\
\hline 2 & B I R O ADM. UMUM & 17 \\
\hline 3 & EKONOMI & 13 \\
\hline 4 & ISIPOL & 11 \\
\hline 5 & KES.MASYARAKAT & 15 \\
\hline 6 & PERTANIAN & 8 \\
\hline 7 & TEKNIK & 8 \\
\hline 8 & HUKUM & 8 \\
\hline 9 & LPPM/UPM & 7 \\
\hline 10 & UPT. PERPUSTAKAAN & 3 \\
\hline 11 & PUSAT INFORMASI & 5 \\
\hline 12 & UNIT USAHA & $\mathbf{1 0 5}$ \\
\hline & \multicolumn{2}{|c|}{ JUMLAH } \\
\hline
\end{tabular}

Data Kepegawaian UG Agustus 2013

\subsection{Metode Analisis}

Untuk mengetahui faktor-faktor yang berpengaruh terhadap kinerja pegawai digunakan analisis regresi linear berganda dengan formulasi sebagai berikut :

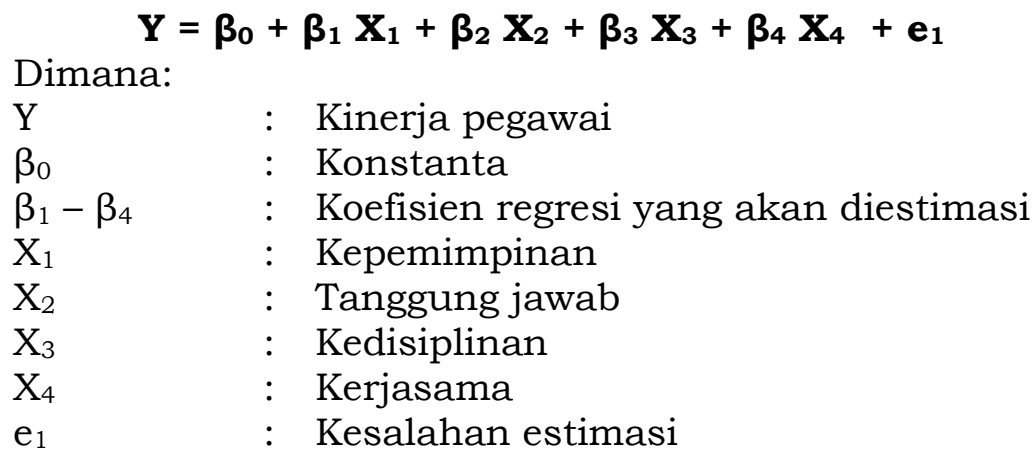

Untuk memperoleh taksiran model regresinya, maka nilai $\beta_{0}$, $\beta_{1-4}$ dihitung dengan mengunakan paket program komputer SPSS (Statistical Package for Social Science). Untuk pengujian hipotesis yang dilakukan adalah sebagai berikut :

1) Untuk mengukur pengaruh seluruh variabel bebas secara bersamaan terhadap variabel terikat, digunakan uji statistik yaitu uji Fisher (uji - F) dengan derajat kemaknaan $95 \%$ atau alpha $(\alpha)=5 \%$.

2) Untuk melihat kedekatan hubungan antara variabel bebas (independent variabel) terhadap variabel terikat (dependent variabel) dijelaskan oleh Koefisien Korelasi (R) apabila nilai $\mathrm{R}>0,5$ berarti hubungan kuat, $\mathrm{R}=$ 0,5 berarti hubungan sedang dan $\mathrm{R}<0,5$ berarti hubungan lemah.

3) Untuk mengestimasi persentase, ketergantungan variabel terikat (dependent variabel) terhadap variabel bebas (independent variabel) dan konstanta intercept dijelaskan oleh Koefisien Determinasi $\left(R^{2}\right)$ atau $(R-$ Square) dan apabila pengaruh intercept dikeluarkan maka $\mathrm{R}$ menjadi $\mathrm{R}^{2}$ terkoreksi (Adj.R-Square)

4) Untuk mengukur signifikan pengaruh masing-masing variabel bebas, $\left(X_{1}\right.$ - $\mathrm{X}_{4}$ ) terhadap variabel terikat $(\mathrm{Y})$, akan digunakan uji statistik yaitu uji student (uji-t). 


\subsection{Definisi Operasional}

3.6.1 Kinerja pegawai pada Universitas Gorontalo adalah hasil kerja yang dapat dicapai oleh suatu organisasi sesuai tugas pokok dan fungsinya dalam rangka mencapai tujuan yang telah direncanakan. Indikatornya adalah kemampuan menyelesaikan pekerjaan sesuai dengan standar yang telah ditetapkan, penyelesaian pekerjaan sesuai dengan rencana kerja, tingkat kesulitan bawahan dalam mengerjakan tugas yang diberikan, serta penyelesaian pekerjaan sesuai dengan waktu yang telah ditetapkan. Skala pengukurannya adalah sebagai berikut:

a. Sangat tinggi diberi skor 5

b. Tinggi diberi skor 4

c. Sedang diberi skor 3

d. Rendah diberi skor 2

e. Sangat rendah diberi skor 1

3.6.2 Kepemimpinan adalah sikap perilaku seseorang yang berkaitan dengan kemampuan pengelolaan baik terhadap orang-orang maupun terhadap pekerjaan, indikatornya adalah sebagai berikut:

a. Kemampuan untuk menggugah semangat dan menggerakkan bawahan.

b. Kemampuan mengemukakan pendapat dengan jelas kepada orang lain.

c. Kemampuan dalam membuat keputusan.

d. Kemampuan menyusun skala prioritas pelaksanaan tugas bawahan.

e. Kemampuan untuk terbuka menerima pendapat bawahan.

3.6.3 Tanggung jawab adalah kesanggupan untuk menyelesaikan pekerjaan yang dibebankan dengan sebaik-baiknya dan tepat pada waktunya serta berani menanggung resiko atas keputusan yang diambilnya. Indiaktornya adalah :

a. Memiliki sikap serta kesadaran yang tinggi dan menunjukkan rasa tanggung jawab yang besar terhadap pekerjaannya.

b. Kesanggupan menyelesaikan pekerjaan yang dibebankan dengan baik serta tepat waktu.

c. Berani menanggung resiko terhadap keputusan yang diambil.

d. Bekerja secara tekun dan berdedikasi tinggi.

e. Memberikan pelayanan yang optimal sesuai bidang tugas.

3.6.4 Kedisiplinan adalah sikap perilaku seseorang yang berkaitan dengan kepatuhan seseorang terhadap aturan-aturan yang berlaku. Indikatornya adalah sebagai berikut :

a. Kehadiran pegawai sesuai peraturan jam kerja.

b. Dalam melaksanakan tugas selalu berpedoman kepada aturan yang ada.

c. Kemampuan berdisiplin kerja yang tinggi dalam pelaksanaan tugas.

d. Konsistensi melaporkan hasil kerja kepada atasan.

e. Sebagai suri tauladan bagi karyawan lain, karena mampu berdisiplin kerja yang tinggi. 
3.6.5 Kerjasama adalah bentuk sikap perilaku yang berkaitan dengan hubungan antar karyawan dalam melaksanakan pekerjaan. Indikatornya adalah :
a. Kesediaan menghargai pendapat orang lain.
b. Kesediaan menerima keputusan yang diambil secara sah.
c. Kesediaan mempertimbangkan usul yang baik dari orang lain.
d. Kemampuan untuk bekerjasama dengan orang lain sesuai dengan waktu dan bidang tugas yang ditentukan.
e. Kesungguhan dalam memperhatikan keutuhan organisasi.

\subsection{Uji Asumsi Klasik}

\section{HASIL PENELITIAN DAN PEMBAHASAN}

Sebelum proses pengujian hipotesis penelitian terlebih dahulu dilakukan uji prasyarat terhadap data penelitian. Uji prasyarat ini dilakukan dengan menggunakan analisis kolmogrof smirnof, dan uji One Way Anova. Uji prasyarat dimaksud meliputi uji normalitas, uji linieritas dan uji homogenitas.

\section{Uji Normalitas}

Pengujian normalitas masing-masing variabel dilakukan dengan maksud untuk mengetahui apakah sebaran data dari setiap variabel tidak menyimpang dari ciri-ciri data yang akan berdistribusi normal. Pengujian normalitas dilakukan menggunakan program komputer SPSS yaitu Uji Kolmogorov-Smirnov Goodness of fit test $(K-S Z)$. Kaidah yang digunakan untuk mengetahui normal atau tidaknya sebaran adalah jika $\mathrm{p}>0,05$; maka sebarannya dinyatakan normal. Adapun hasil uji normalitas sebaran dapat dilihat dalam Tabel 17.

Tabel 17. Rangkuman Hasil Uji Normalitas

\begin{tabular}{|c|l|c|c|c|}
\hline No. & \multicolumn{1}{|c|}{ Variabel } & $K-S Z$ & $P(S I g)$ & Keterangan \\
\hline 1 & Kinerja Pegawai $(Y)$ & 1.014 & 0.075 & Normal \\
\hline 2 & Kepemimpinan $\left(\mathrm{X}_{1}\right)$ & 1.025 & 0,068 & Normal \\
\hline 3 & Tanggung Jawab $\left(\mathrm{X}_{2}\right)$ & 1.088 & 0.065 & Normal \\
\hline 4 & Kedisiplinan $\left(\mathrm{X}_{3}\right)$ & 1.063 & 0.067 & Normal \\
\hline 5 & Kerjasama $\left(\mathrm{X}_{4}\right)$ & 0.986 & 0.102 & Normal \\
\hline
\end{tabular}

Sumber : Data primer diolah, 2013

\section{Uji Linieritas}

Uji linieritas pengaruh yang digunakan untuk menentukan kelinieran antar variabel dalam penelitian ini adalah dengan melihat nilai $\mathrm{F}$ pada taraf signifikansi 5\%. Jika $\mathrm{p}<0,05$ maka pengaruh antara variabel bebas dengan variabel terikat bersifat linier. Hasil uji linieritas dapat dilihat dalam Tabel 18 berikut ini.

Tabel 18. Rangkuman Hasil Uji Linieritas

\begin{tabular}{|c|c|c|c|c|}
\hline No. & Variabel & $\mathrm{F}$ & $\mathrm{p}($ Sig) & Keterangan \\
\hline 1 & $\mathrm{X} 1$ atas $\mathrm{Y}$ & 50.716 & 0,000 & Linear \\
\hline 2 & $\mathrm{X} 2$ atas Y & 8.038 & 0,000 & Linear \\
\hline 3 & $\mathrm{X} 3$ atas Y & 37.203 & 0.000 & Linear \\
\hline 4 & $\mathrm{X} 4$ atas Y & 38.153 & 0.000 & Linear \\
\hline
\end{tabular}

Sumber : Data primer diolah, 2013 


\section{Uji homogenitas}

Uji homogenitas bertujuan untuk mengetahui apakah populasi mempunyai varians yang sama (homogen). Uji homogenitas dilakukan dengan menggunakan komputer (SPSS) dengan uji kolmogorov-smirnov (lihat Lampiran 5 ) dengan kriteria sebagai berikut :

a. Jika nilai signifikan $<0,05$ berarti data homogen.

b. Jika nilai signifikan $>0,05$ berarti data tidak homogen Hasil uji homogenitas data disajikan pada Tabel 19.

Tabel 19. Tabel Hasil Uji Homogenitas

\begin{tabular}{|l|l|c|c|c|}
\hline No. & \multicolumn{1}{|c|}{ Variabel } & $\begin{array}{c}\text { Levane } \\
\text { Statistic }\end{array}$ & Nilai Sig. & Keterangan \\
\hline 1 & Kepemimpinan $\left(\mathrm{X}_{1}\right)$ & 3.445 & 0.001 & Homogen \\
\hline 2 & Tanggung Jawab $\left(\mathrm{X}_{2}\right)$ & 3.694 & 0.000 & Homogen \\
\hline 3 & Kedisiplinan $\left(\mathrm{X}_{3}\right)$ & 9.305 & 0.000 & Homogen \\
\hline 4 & Kerjasama $\left(\mathrm{X}_{4}\right)$ & 4.002 & 0.000 & Homogen \\
\hline
\end{tabular}

Sumber : Data primer diolah, 2013

Berdasarkan hasil uji prasyarat analisis sebagaimana disajikan dalam Tabel 17, Tabel 18, dan Tabel 19 tersebut, diketahui bahwa analisis regresi memenuhi syarat untuk digunakan. Hasil uji selengkapnya dapat dilihat pada Lampiran.

\subsection{Analisis Hasil Penelitian}

Pengaruh faktor kepemimpinan, tanggung jawab, kedisiplinan dan kerjasama, dapat diketahui setelah dilakukan pengujian hipotesis. Pengujian hipotesis menggunakan analisis statistik inferensial dengan teknik analisis regresi linear berganda. Hasil pengujian hipotesis secara lengkap pengaruh variable kepemimpinan, tanggung jawab, kedisiplinan dan kerjasama terhadap kinerja pegawai dapat dilihat pada Lampiran 6. Hasil analisis regresi linear berganda dapat dilihat pada Tabel 20.

Tabel 20. Hasil Regresi Kepemimpinan $\left(\mathrm{X}_{1}\right)$, Tanggung Jawab $\left(\mathrm{X}_{2}\right)$, Kedisiplinan $\left(\mathrm{X}_{3}\right)$, Kerjasama $\left(\mathrm{X}_{4}\right)$ terhadap Kinerja Pegawai $(\mathrm{Y})$

\begin{tabular}{|l|c|c|c|c|}
\hline Variabel terikat & $\begin{array}{c}\text { Variabel } \\
\text { Bebas }\end{array}$ & $\mathrm{B}$ & $\mathrm{T}$ & Sig \\
\hline & Constant & 0.381 & 2.021 & 0,048 \\
$\mathrm{Y}$ & $\mathrm{X}_{1}$ & 0.369 & 4.770 & 0,000 \\
& $\mathrm{X}_{2}$ & 0.298 & 4.754 & 0,000 \\
& $\mathrm{X}_{3}$ & 0.212 & 2.121 & 0,036 \\
& $\mathrm{X}_{4}$ & 0.248 & 2.464 & 0.012 \\
\hline R. Square & $: 0.827$ & \\
$\mathrm{R}$ & $: 0.909$ & \\
F hitung & $: 119.192$ & \\
Signifikansi F (P) & $: 0.000$ \\
$\mathrm{~N}$ & $: 105$ & \\
\hline
\end{tabular}

Sumber : Data primer diolah, 2013

Dari Tabel 20 di atas diperoleh persamaan sebagai berikut:

$$
Y=0.381+0.369 X_{1}+0,298 X_{2}+0,212 X_{3}+0.248 X_{4}
$$


Dari persamaan regresi tersebut diperoleh pengaruh kepemimpinan dengan nilai koefisien sebesar 0,369 berarti jika kepemimpinan ditingkatkan akan meningkatkan kinerja pegawai dengan ketentuan variabel lain konstan. Analisis nilai t hitung sebesar 4.770 dengan tingkat signifikansi 0,000 (sig $<\square 0,05$ ) berarti $\mathrm{H}_{1}$ diterima yang menunjukkan bahwa terdapat pengaruh yang positif dan signifikan antara kepemimpinan dengan kinerja pegawai $(\mathrm{Y})$.

Tanggung jawab dengan nilai koefisien sebesar 0,298 berarti jika tanggung jawab meningkat maka akan meningkatkan kinerja pegawai dengan ketentuan variabel lain konstan. Analisis t hitung sebesar 4,754 dengan tingkat signifikansi sebesar 0.000 (sig $<0,05)$ berarti $\mathrm{H}_{1}$ diterima yang menunjukkan bahwa terdapat pengaruh yang positif dan signifikan antara tanggung jawab dengan kinerja pegawai $(\mathrm{Y})$.

Kedisiplinan dengan nilai koefisien sebesar 0,212 berarti jika kedisiplinan ditingkatkan maka akan meningkatkan kinerja pegawai dengan ketentuan variabel lain konstan. Analisis t hitung sebesar 2.121 dengan tingkat signifikansi sebesar 0.036 ( $\mathrm{sig}<0,05)$ berarti $\mathrm{H}_{1}$ diterima yang menunjukkan bahwa terdapat pengaruh yang positif dan signifikan antara kedisiplinan dengan kinerja pegawai $(\mathrm{Y})$.

Kerjasama dengan nilai koefisien sebesar 0,248 berarti jika kerjasama meningkat maka akan meningkatkan kinerja pegawai dengan ketentuan variabel lain konstan. Analisis $t$ hitung sebesar 2.564 dengan tingkat signifikansi sebesar 0.012 ( $\mathrm{sig}<0,05)$ berarti $\mathrm{H}_{1}$ diterima yang menunjukkan bahwa terdapat pengaruh yang positif dan signifikan antara kerjasama dengan kinerja pegawai $(\mathrm{Y})$.

Selanjutnya nilai $\mathrm{R}$ square sebesar 0,827 ini berarti koefisien determinasi faktor kepemimpinan $\left(\mathrm{X}_{1}\right)$, tanggung jawab $\left(\mathrm{X}_{2}\right)$, kedisiplinan $\left(\mathrm{X}_{3}\right)$, dan kerjasama $\left(\mathrm{X}_{4}\right)$ terhadap kinerja pegawai sebesar 0,827 atau $82,7 \%$ variansi kinerja pegawai $(\mathrm{Y})$ dapat dijelaskan oleh keempat variabel ini. Sedangkan sisanya $17.3 \%$ dipengaruhi oleh faktor lain di luar model.

Sedangkan hubungan (R) kepemimpinan $\left(\mathrm{X}_{1}\right)$, tanggung jawab $\left(\mathrm{X}_{2}\right)$, kedisiplinan $\left(\mathrm{X}_{3}\right)$, dan kerjasama $\left(\mathrm{X}_{4}\right)$ terhadap kinerja pegawai sebesar 0,909 yang menunjukkan hubungan yang sangat kuat.

\subsection{Pembahasan Hasil Penelitian}

Berdasarkan hasil analisis statistik menunjukkan bahwa faktor kepemimpinan $\left(\mathrm{X}_{1}\right)$, tanggung jawab $\left(\mathrm{X}_{2}\right)$, kedisiplinan $\left(\mathrm{X}_{3}\right)$ dan kerjasama $\left(\mathrm{X}_{4}\right)$ berpengaruh secara positif dan signifikan terhadap kinerja pegawai $(\mathrm{Y})$ pada Universitas Gorontalo. Hal ini berarti dalam rangka meningkatkan kinerja pegawai, keempat faktor tersebut perlu diperhatikan secara sungguhsungguh dan terpadu karena merupakan satu kesatuan sistem yang tidak dapat dipisahkan satu dengan yang lainnya sebagai implementasi dan cerminan pengaruh pendidikan dan pelatihan kepemimpinan.

Secara parsial ke empat faktor tersebut berpengaruh terhadap kinerja pegawai. Selengkapnya dapat dibahas sebagai berikut :

\section{Pengaruh Kepemimpinan Terhadap Kinerja Pegawai}

Hasil analisis statistik menunjukkan bahwa faktor kepemimpinan mempunyai pengaruh terhadap kinerja pegawai yaitu sebesar 0.369. hasil penelitian relevan dengan apa yang dihasilkan oleh penelitian sebelumnya Ridwan (2011) pada Universitas Hasanuddin Makassar, Rahmat (2004) pada 
Dinas Tata Ruang dan Permukiman Provinsi Sulawesi Selatan dan Ansar (2002) pada Kantor Informasi Penyuluhan Pertanian Kabupaten Maros.

Maju mundurnya organisasi, dinamis statisnya organisasi, tumbuh kembangnya organisasi, mati hidupnya organisasi, senang tidaknya seseorang bekerja dalam suatu organisasi, serta tercapai tidaknya tujuan organisasi sebagian ditentukan oleh tepat atau tidak kepemimpinan yang diterapkan dalam organisasi yang bersangkutan. (Sutarto, 2001: 30)

Kepemimpinan merupakan salah satu realisasi pendidikan dan pelatihan kepemimpinan. Keberhasilan meningkatkan faktor kepemimpinan peserta diklat membuat pegawai menjadi bersungguh-sungguh, percaya diri, berkemampuan, berani bertanggung jawab serta bercita-cita.

Kemampuan manajerial seseorang terhadap orang-orang maupun pekerjaan sangat mempengaruhi kinerja individu maupun organisasi. Dengan demikian diharapkan pada organisasi untuk lebih memperhatikan aspek kepemimpinan agar dapat memberi kontribusi yang berarti dalam peningkatan kinerja pegawai.

\section{Pengaruh Tanggung jawab Terhadap kinerja pegawai}

Berdasarkan PP Nomor 10 Tahun 1979, tanggung jawab adalah kesanggupan untuk menyelesaikan pekerjaan yang dibebankan dengan sebaik-baiknya dan tepat pada waktunya serta berani menanggung resiko atas keputusan yang diambilnya. Pada penelitian ini menunjukkan bahwa faktor tanggung jawab berpengaruh sebesar 0.298 signifikan terhadap peningkatan kinerja pegawai. Hal ini didukung oleh penelitian Hasanuddin (2003) bahwa tanggung jawab berpengaruh signifikan terhadap kinerja pegawai.

Sultan (2000 : 43) mengemukakan bahwa tanggung jawab dalam meningkatkan prestasi kerja mencakup : bekerja secara tekun dan berdedikasi tinggi, memberikan pelayanan yang optimal kepada masyarakat, bertanggung jawab, mengkoordinasikan dalam sumber daya organisasi, bekerja secara efisien dan efektif sesuai analisis organisasi, memberikan solusi pada manajemen organisasi sebagai andil tanggung jawab memberdayakan dan mendayagunakan organisasi.

\section{Pengaruh Kedisiplinan Terhadap Kinerja Pegawai}

Disiplin kerja mencakup tingkat kepatuhan atau ketaatan pegawai dalam mengikuti seluruh tata tertib kerja organisasi yang berlaku pada Universitas Gorontalo. Disiplin kerja relatif berpengaruh terhadap kinerja pegawai dan organisasi. Apa dan bagaimana disiplin kerja pegawai tersebut, terlihat dari beberapa indikator yang diteliti : (a) ketaatan terhadap peraturan, (b) ketepatan penggunaan waktu, (c) ketepatan dalam pelaksanaan tugas, dan (d) kepatuhan pada pimpinan.

Analisis terhadap disiplin kerja pegawai pada Universitas Gorontalo dalam pelaksanaan tugasnya menunjukkan bahwa tingkat kedisiplinan pegawai berada dalam kategori sedang. Olehnya itu masih perlu peningkatan kedisiplinan terhadap pegawai Universitas Gorontalo. Peningkatan kedisiplinan pegawai dapat ditempuh dengan pemberlakuan aturan yang ketat oleh pimpinan terhadap semua pegawai yang ada di Universitas Gorontalo. Pegawai yang melanggar harus diberikan sanksi sesuai dengan peraturan yang ada.seperti yang berlaku di Universitas Gorontalo bahwa 
setiap pegawai yang melanggar (tidak mengikuti coffe morning) tiga kali berturut-turut akan di tahan gajinya. Tingkat kedisiplinan pegawai pada Universitas Gorontalo mungkin dapat menjadi contoh bagi pegawai di instansi lain.

Peningkatan disiplin pegawai akan mampu meningkatkan kinerja pegawai. Hal ini berdasar karena pegawai yang disiplin akan mampu mengerjakan tugas-tugas yang diberikan selesai tepat pada waktunya, sedangkan pegawai yang malas (kurang disiplin) tingkat penyelesaian pekerjaannya sangat rendah atau bahkan boleh dikata bahwa pekerjaanya selalu ditunda.

Hasil penelitian ini sejalan dengan pendapat Haryono (2006 : 131) menyatakan bahwa disiplin mengandung beberapa unsur, yaitu : (1) berisi moral yang mengatur tata kehidupan, (2) pengembangan ego dengan segala masalah intrinsik yang mengharuskan orang untuk menentukan pilihan, (3) pertumbuhan kekuatan untuk memberi jawaban terhadap setiap aturan yang disampaikan, dan (4) penerimaan otoritas tambahan yang membantu seseorang untuk membentuk kemampuan dan keterbatasan hidup.

\section{Pengaruh Kerjasama Terhadap Kinerja Pegawai}

Salah satu teori kepemimpinan menyatakan bahwa, kepemimpinan merupakan rangkaian kegiatan penataan berupa kemampuan mempengaruhi perilaku orang lain dalam situasi tertentu agar bersedia bekerjasama untuk mencapai tujuan yang telah ditetapkan (Sutarto, $2001: 26$ )

Merujuk pada pernyataan di atas, maka aspek kerja sama merupakan hal yang penting bagi pegawai dalam berkoordinasi ataupun dalam melaksanakan tugas pokok dan fungsi organisasi yang menjadi tanggung jawabnya. Kerjasama memiliki peranan penting untuk meningkatkan kinerja pegawai mulai dari proses perencanaan, pelaksanaan, monitoring dan evaluasi yang pada akhimya dapat berpengaruh pada pencapaian tujuan organisasi.

Hasil penelitian menunjukkan bahwa faktor kerjasama berpengaruh signifikan sebesar 0,248 terhadap kinerja pegawai pada Universitas Gorontalo. Hasil penelitian ini didukung oleh hasil penelitian Muhlis (2002) dimana variabel kerjasama berpengaruh secara signifikan terhadap kinerja pegawai.

Berdasarkan hasil yang diperoleh, maka diharapkan agar organisasi dapat memberikan pelatihan untuk meningkatkan kerjasama antar pegawai dalam organisasi dengan senantiasa mengatasi berbagai kekurangan dan kelemahan sehingga pegawai dapat bersinergi dalam beraktivitas demi terwujudnya tujuan organisasi yang diharapkan.

\section{SIMPULAN DAN SARAN}

\subsection{Simpulan}

Berdasarkan hasil penelitian dan pembahasan yang telah dikemukakan di atas dapat ditarik beberapa kesimpulan sebagai berikut :

1. Secara simultan menunjukkan bahwa kepemimpinan, tanggung jawab, kedisiplinan dan kerjasama berpengaruh terhadap kinerja Pegawai

2. Secara parsial menunjukkan bahwa kepemimpinan berpengaruh secara positif dan dominan terhadap kinerja pegawai Universitas Gorontalo, 
yang menunjukkan bahwa peningkatan jiwa kepemimpinan akan meningkatkan kinerja pegawai

3. Secara parsial menunjukkan bahwa tanggung jawab berpengaruh secara positif dan signifikan terhadap kinerja pegawai Universitas Gorontalo yang berarti bahwa peningkatan jiwa tanggung jawab akan meningkatkan kinerja pegawai.

4. Secara parsial menunjukkan bahwa kedisiplinan berpengaruh secara positif dan signifikan terhadap kinerja pegawai Universitas Gorontalo. Dalam artian bahwa peningkatan tingkat kedisiplinan akan meningkatkan kinerja pegawai.

5. Secara parsial menunjukkan bahwa kerjasama berpengaruh secara positif dan signifikan terhadap kinerja pegawai Universitas Gorontalo, yang berarti bahwa peningkatan kerjasama akan meningkatkan kinerja pegawai.

\subsection{Saran}

1. Perlunya peningkatan kinerja pegawai Universitas Gorontalo dengan peningkatan kualitas dan kuantitas hasil pekerjaan.

2. Perlunya peningkatan jiwa kepemimpinan kepada semua pegawai melalui pelatihan kepemimpinan.

3. Perlunya peningkatan tanggung jawab oleh setiap pegawai dalam melaksanakan tugas pokok dan fungsinya.

4. Perlunya peningkatan kedisiplinan kepada semua pegawai terutama disiplin terhadap waktu dan aturan kerja.

5. Perlunya peningkatan kerjasama diantara rekan sejawat, pimpinan dan bawahan agar pencapaian kinerja organisasi lebih optimal.

\section{REFERENSI}

Arikunto Suharsini, 1999. Prosedur Penelitian: Suatu Pendekatan Praktek, Rineka Cipta, Jakarta.

Dessler, Gary, 2010, Manajemen Sumber Daya Manusia, Edisi Sepuluh, PT. Indeks Permata Puri Media: Jakarta.

Hamalik, Oemar. 2001. Pengembangan sumber daya manusia. PT. Bumi Aksara, Jakarta.

Haryono Sudriamunawar,2006. Kepemimpinan, Peran Serta dan Produktivitas. Mandar Maju,Bandung.

Hasibuan H. Malayu, 2001. Manajemen Sumber Daya Manusia. PT. Aksara. Jakarta.

Indrawijaya, Wahyu Suprapti,2001. Kepemimpinan Dalam Organisasi. LANRI, Jakarta.

Jayakusuma. 2002. Prestasi Dalam Dunia Kerja. PT. Gramedia Pustaka Utama, Jakarta.

Mangkunegara, A.A. Anwar Prabu, 2011, Manajemen Sumber Daya Manusia Perusahaan, Cet. Kesepuluh, Bandung: PT Remaja Rosdakarya.

Martoyo Susilo, 2000. Manajemen Sumber Daya Manusia. Edisi Keempat, BPFE, Yogyakarta.

Mustopadidjaya, A.R, 2000. Pedoman Penyusunan Pelaporan Akuntabilitas Kinerja Instansi Pemerintah, Penerbit LN-RI, Jakarta, 1999. 
Prasetya, Irawan, 2000. Manajemen Sumber Daya Manusia. STIA LAN Pess, Jakarta.

Ridwan,2003. Skala Pengukuran Variabel-Variabel Penelitian, Alfabeta, Bandung.

Samsudin, Sadili, 2010, Manajemen Sumber Daya Manusia, Cet. Ketiga, Bandung: Pustaka Setia.

Sjafri Mangkuprawira,2004. Manajemen Sumber Daya Manusia Strategik. Ghalia Indonesia,2004.

Sri Murtini, Judianto, 2001. Kepemimpinan Di Alam Terbuka, LAN Republik Indonesia, Jakarta.

Sugiyono, 2002. Metode Penelitian Administrasi. Bandung:Tatsito.

Sultan, 2000. Pendidikan, Keterampilan, dan Pelatihan Sumber Daya Manusia. PT. Grafindo Persada Nusantara, Jakarta.

Sutarto, 2001. Dasar-Dasar Kepemimpinan Administrasi, Gadjah Mada University Press. Yogyakarta.

Umar, Husen. 2003. Sumber Daya Manusia Dalam Organisasi, Gramedia Pustaka Utama, Jakarta.

Veithzal Rivai, Ahmad Fawzi Mohd. Basri, 2005. Performance Appraisal. PT. RajaGrafindo Persada, Jakarta.

Werther, Jr W.B \& Davis, K, 1996. Human Resouyrces and Personnel Management, Fifth Edition, International Edition, McGraw-Hill, Inc.

Winardi, J,. 2001. Motivasi dan Pemotivasian dalam Manajemen. Penerbit Rajawali Press, Jakarta.

Yuniarsih, Tjutju, 2011, Manajemen Sumber Daya Manusia, Cet. Ketiga, Bandung: Alfabeta 